\title{
Effect of growth promoters (probiotics) supplementation on performance, rumen activity and some blood constituents in growing lambs
}

\author{
Hany Hillal, Gamal El-Sayaad and Mohamed Abdella \\ Department of Animal Production, Faculty of Agriculture, Benha University, Egypt
}

\begin{abstract}
The current study examined the effects of probiotics (Pronifer and More-yeast) supplementation to growing lambs. 25 crossbred (OsimixRahmani) growing lambs of about 6-8 months age and an average initial live body weight of $25 \mathrm{~kg}$ were used. Lambs divided into five groups (5 lambs for each group) and the experimental period lasted for 169 days. The control group $T_{1}$ received concentrate feed mixture (CFM), group $T_{2}$ and $T_{3}$ received 1.5 and $3 \mathrm{~kg}$ Pronifer/Mg (megagram) CFM and group $\mathrm{T}_{4}$ and $\mathrm{T}_{5}$ received 2.5 and $5 \mathrm{~kg}$ More-yeast/ Mg CFM, respectively. Rumen liquor and blood samples were taken and digestibility trial was conducted at the end of the experiment. Results showed higher digestibility values for crude protein $(P<0.05)$ in $\mathrm{T}_{3}$ and $\mathrm{T}_{4}$ when compared to control. Nutritive ratio was lower $(P<0.05)$ in groups $T_{3}$ and $T_{4}$ than in group $T_{2}$. More-yeast supplementation improved dry matter intake $(P<0.001)$, while a reverse trend was observed with Pronifer supplementation. All treatments had little effect on ruminal liquor except ruminal ammonia concentration in $\mathrm{T}_{5}$ was lower $(P<0.05)$ than other treatments. The differences in most blood plasma parameters due to treatment effect were not significant, except plasma urea and globulin concentrations increased $(P<0.05)$ with $\mathrm{T}_{5}$ treatment. The obtained results appear to indicate that Moreyeast supplementation improved lambs performance and digestibility, whereas, Pronifer supplementation enhanced digestibility.
\end{abstract}

Keywords: probiotics, performance, rumen activity, blood constituents and growing lambs

\section{Zusammenfassung}

\section{Auswirkung der Wachstumsförderer (Probiotika) Supplementierung auf die Leistung, Pansenaktivität und einige Blutbestandteile in wachsende Lämmer}

Die aktuelle Studie untersuchte die Auswirkungen von Probiotika (Pronifer und More-yeast) Supplementierung auf wachsende Lämmer. Es wurden 25 Kreuzungstiere (Osimi×Rahmani), ca. 6-8 Monaten alt, mit einem durchschnittlichen Körpergewicht von $25 \mathrm{~kg}$ zu Beginn der Studie verwendet. Die Lämmer wurden in 5 Gruppen mit je 5 Lämmern aufgeteilt. Das Experiment dauerte 169 Tage. Die Kontrollgruppe $\left(T_{1}\right)$ erhielt eine Kraftfutter-Mischung (CFM), die Gruppen $T_{2}$ und $T_{3}$ erhielten 1,5 bzw. 3 kg Pronifer/Tonne CFM und die Gruppen $\mathrm{T}_{4}$ und $\mathrm{T}_{5}$ erhielten 2,5 und $5 \mathrm{~kg}$ More-yeast/Tonne CFM. Es wurden Pansensaft und Blutproben entnommen und am Ende des Experiments wurde eine Verdaulichkeitsstudie 
durchgeführt. Die Ergebnisse zeigten eine höhere Verdaulichkeit für Rohprotein $(P<0,05)$ in $\mathrm{T}_{3}$ und $\mathrm{T}_{4}$ im Vergleich zur Kontrollgruppe. Das nutritive Verhältnis war niedriger $(P<0,05)$ in den Gruppen $\mathrm{T}_{3}$ und $\mathrm{T}_{4}$ als in der Gruppe $\mathrm{T}_{2}$. More-yeast Supplementierung verbesserte die Trockensubstanzaufnahme $(P<0,001)$ der Lämmer, während ein umgekehrter Trend mit Pronifer Supplementierung erkennbar war. Alle Behandlungen hatten wenig Einfluss auf die gemessenen Parameter im Pansen außer, dass die ruminale Ammoniakkonzentration in Gruppe $\mathrm{T}_{5}$ am geringsten war $(P<0,05)$. Die meisten Blutplasmaparameter wurden durch die Behandlung nicht beeinflusst mit der Ausnahme, dass Harnstoff und Globulin erhöht waren $(P<0,05)$ in der $T_{5}$ Behandlung. Die erhaltenen Ergebnisse deuten darauf hin, dass die Lämmer, die mit More-yeast gefüttert wurden, eine bessere Leistung und Verdaulichkeit zeigten, während Pronifer Supplementierung die Verdaulichkeit verbessert.

Schlüsselwörter: Probiotika, Leistung, Pansenaktivität, Blutbestandteile und Lämmer

\section{Introduction}

Probiotics are being explored as substitutes of antibiotic feed additives that improve gut health and promote animal performance. Microbial products are known to promote rumen metabolic development by modulating rumen function and fermentation activity of its microflora, which improves ruminant production performance (Tripathi \& Karim 2011). Probiotic growth promoters have been used as supplements in animal feeds for more than seven decades to enhance growth and decrease feed:gain ratio (Dawson 1993). Probiotics are viable microorganisms that exhibit a beneficial effect on the health of the host by improving its intestinal microbial balance (Cremonini et al. 2002).

Most evidences for such effects come from results of intensive studies of microbial activities in the rumen of cattle and sheep (Windschitl 1992 and Dawson 1993). Pronifer is a fermentation product consisting of a bacterial cocktail of specific lactic acid producing bacteria. As a probiotic agent, it may act through improving the balance of the intestinal microflora (Games 1987). In addition, Dawson et al. (1990) reported a decrease in ruminal pH and an increase in cellulolytic ruminal bacterial numbers in steers fed hay supplemented with lactic acid bacteria (L. acidophilus). Also, Pronifer improves health, performance, minimize diarrhoea and increase growth rates (Bohm \& Srour 1995).

Yeast product supplementation has several benefits in ruminant nutrition which have been demonstrated an increase in nutrient digestibility, alteration of the proportion of volatile fatty acids produced in the rumen, reduction in ruminal ammonia, and increase of ruminal microorganism population (Chaucheyras-Durand et al. 2008). Furthermore, yeast culture supplementation in growing lamb has the potential to improve intake and growth and can substitute antibiotics as growth promoting feed additive (Tripathi \& Karim 2011). Dawson (1992) mentioned that yeast stimulates rumen bacteria and enhance lactate and ammonia utilization resulting in moderate ruminal $\mathrm{pH}$ and increases in microbial population which lead to increased in fibre digestion and protein synthesis in the rumen. Yeast culture improved feed intake, weight gain and feed conversion in growing ruminants (Salem et al. 2000 and El-Waziry et al. 2000). Yeast also provides vitamins to support the growth of rumen fungi (Chaucheyras-Durand et al. 1995). 
The objective of this study was to investigate the effect of adding Pronifer and More-yeast supplements as growth promoters on performance, digestibility, rumen activity and blood parameters in growing crossbred lamb.

\section{Material and methods}

Lambs, treatments and samples

Twenty five crossbred (OsimixRahmani) growing lambs, about 6-8 months old with an average initial live body weight (LBW) of $25.04 \pm 0.36 \mathrm{~kg}$ were used in this experiment. The experiment was carried out at Moshtohor Animal Farm, Ministry of Agriculture, Egypt. The animals were divided into five groups on the basis of initial LBW and age. Each group contained five animals. The feeding trial lasted for 168 days and animals were fed individually. Lambs were assigned at random to one of the five experimental diets as shown in Table 1.

Table 1

Feeding regimes

\begin{tabular}{ll}
\hline Treatments & Experimental diets \\
\hline $\mathrm{T}_{1}$ & Control diet (CD): CFM* + wheat straw ad libitum \\
$\mathrm{T}_{2}$ & $\mathrm{CD}+1.5 \mathrm{~kg}$ Pronifer $/ \mathrm{Mg}$ CFM \\
$\mathrm{T}_{3}$ & $\mathrm{CD}+3 \mathrm{~kg}$ Pronifer $/ \mathrm{Mg}$ CFM \\
$\mathrm{T}_{4}$ & $\mathrm{CD}+2.5 \mathrm{~kg}$ More-yeast $/ \mathrm{Mg}$ CFM \\
$\mathrm{T}_{5}$ & $\mathrm{CD}+5 \mathrm{~kg}$ More-yeast $/ \mathrm{Mg}$ CFM \\
\hline
\end{tabular}

${ }^{*}$ CFM: concentrate feed mixture consisted of yellow corn $65 \%$, wheat bran $15 \%$, decorticated soybean $10 \%$, decorticated lin seed $5 \%$, molasses $3 \%$, calcium carbonate $1.4 \%$, sodium chloride $0.5 \%$ and Min and Vit. Premi $0.1 \%$

The diets used in this study consisted of wheat straw, concentrate feed mixture (CFM) and Pronifer or More-yeast.

The chemical analysis of the experimental feeds used is presented in Table 2. Pronifer is a probiotic feed additive which contains:

- viable lactic acid bacteria (approx. $10^{6} \mathrm{CFU} / \mathrm{g}$ ) (Lactobacillus planetarium, L. brevis, L. fermeritum, L. casei, and Pediococcus acidilacticii)

- lactic acid fermentation metabolites and enzymes (organic acids, glucosidase, and peptidase enzymes)

- free (soluble) amino acids and short-chain peptides (Srour et al. 2000).

Table 2

Chemical analysis of the experimental diets

\begin{tabular}{lccrrrrr}
\hline Items & $\mathrm{DM}, \%$ & $\mathrm{5}$ Composition on DM basis, \% \\
& & $\mathrm{OM} \%$ & $\mathrm{CP}, \%$ & $\mathrm{CF}, \%$ & $\mathrm{EE}, \%$ & $\mathrm{NFE}, \%$ & Ash, \% \\
\hline Wheat straw & 95.95 & 88.60 & 2.87 & 43.88 & 1.80 & 40.05 & 11.40 \\
CFM & 91.31 & 95.62 & 12.00 & 4.24 & 12.91 & 66.47 & 4.38 \\
\hline
\end{tabular}

DM: dry matter, OM: organic matter, CP: crude protein, CF: crude fibre, EE: ether extract, NFE: nitrogen-free extract

This probiotic was purchased from Schwester P.G.E. Company (Austria) by Egyptian Ven Thred Company. 
More-yeast is a probiotic including live yeast (saccharomyces cerevisiae) and other directfed microbials including strains of lactobacillus, streptococcus, aspergillus and several others. The live yeast contained pure strains of saccharomyces cerevisiae grown in purified cane and beet molasses solutions under the most stringently controlled chemical, bacteriological and sanitary conditions. More-yeast was imported from Norchem, Inc. (Hauppauge, NY, USA) Company by International Marketing Center (Cairo, Egypt).

Lambs were adapted to the experimental diets for two weeks before the start of the feeding trial. Wheat straw was offered ad libitum, while CFM was allowed according to the NRC (1985) recommendations based on LBW. Diets were offered twice daily in two equal portions at 8.00 a.m. and 4.00 p.m. Feed intake and refusals (if any) were recorded daily. Lambs were weighed every second week in the morning before feeding. At the end of the experiment, a digestibility trial was conducted using three animals from each experimental group assigned at random and maintained in individual digestibility cages. Lambs were weighed at the start and end of each trial.

The digestibility trial consisted of 15 days as a preliminary period, followed by 10 days as the collection period. The experimental rations were weighed and fed according to NRC (1985). Wheat straw was offered ad libitum. Feed intake was recorded daily once at 8.00 a.m. Faeces were collected from each individual animal once daily before the morning meal, the refusal of feeds (if any) were collected and recorded daily before offering the new feed. Daily faeces excreted from each lamb was weighed and $10 \%$ of the fresh faeces was taken and dried at $60{ }^{\circ} \mathrm{C}$ for $24-72 \mathrm{~h}$ to determine dry matter of the faeces. Composite samples from the daily dried faeces, for each lamb, were mixed, ground and stored in refrigerator for subsequent chemical analysis. Representative samples of experimental diets, refusals and faeces were analysed for dry matter (DM), organic matter (OM), crude protein (CP), ether extract (EE), crude fibre (CF) and ash contents according to AOAC (1999) methods, while nitrogen-free extract (NFE) was calculated by differences.

Rumen liquor samples were taken individually from three lambs of each experimental group at four times during the feeding trial period (0, 8, 16 and 24 weeks). Rumen samples were taken using a rubber stomach tube connected to a vacuum pump (Nagah 2002), before feeding and at 3 and $6 \mathrm{~h}$ post-feeding. Rumen samples were strained through four layers of cheese cloth. Rumen liquor analysis included ruminal $\mathrm{pH}$ value ( $\mathrm{pH}$ meter), Ammonia nitrogen $\left(\mathrm{N}-\mathrm{NH}_{3}\right)$ concentration determined immediately according to Conway (1962). Total volatile fatty acid (TVFA) concentrations were determined by the steam distillation method (Abou-Akkada \& El-Shazly 1964).

Blood samples were taken at 0, 8, 16 and 24 weeks throughout the feeding period. The blood samples were taken from jugular vein of three lambs from each experimental group before morning feeding by vein puncture and were put into $10 \mathrm{ml}$ heparinized test tubes. Blood samples were immediately centrifuged at $3500 \mathrm{rpm}$ for $15 \mathrm{~min}$ to separate plasma. Blood plasma samples were immediately frozen at $-20^{\circ} \mathrm{C}$ and stored until analysis. Commercial kits (Diamond Diagnostics Co., Egypt) were used to determine total protein $(\mathrm{TP})$, albumin (Al), urea (U), cholesterol (Ch), creatinine and plasma transaminases; glutamicoxaloacetic-transaminase (GOT) and glutamic-pyruvic-transaminase (GPT), according to Armstrong \& Carr (1964), Doumas et al. (1971), Patton \& Crouch (1977), Allain et al. (1974), Henry (1965) and Reitman \& Frankel (1957), respectively. While, globulin (G) was calculated by 
subtracting the Al concentration from the TP value and Al:G ratio was measured by dividing albumin value by its corresponding globulin value.

\section{Statistical analysis}

The data were statistically analysed according to SAS (1999). The statistical models used in this study were as follows:

$$
Y_{i j}=U+A_{i}+E_{i j}
$$

where $Y_{i j}$ is the observed response, $U$ is the overall mean, $A_{i}$ is the effect of treatment (growth promoters), $E_{i j}$ is the experimental error. The differences among groups were tested by Duncan's multiple rang test (Duncan 1955).

\section{Results}

\section{Nutrients digestibility and feeding values}

The average digestion coefficients and feeding values of experimental diets are shown in Table 3. The present results showed that lambs fed $T_{1}$ (control) recorded numerically lowest digestibility values for all feed nutrients (DM, OM, CP, CF, EE and NFE). The differences in nutrients digestibility due to treatment effect were not significant except for CP digestibility. Lambs of $\mathrm{T}_{3}$ ( $3 \mathrm{~kg}$ Pronifer/Mg CFM) and $\mathrm{T}_{4}(2.5 \mathrm{~kg}$ More-yeast $/ \mathrm{Mg}$ CFM) showed the highest $C P$ digestibility values. The lowest digestible crude protein (DCP) values were shown by $T_{2}$ and $T_{1}(P<0.05)$ while the highest ones were recorded by $T_{3}$ and $T_{4}(P<0.05)$. In general, $T_{3}(3 \mathrm{~kg}$ Pronifer/Mg CFM) and $\mathrm{T}_{4}(2.5 \mathrm{~kg}$ More-yeast/Mg CFM) showed the best feeding values (DCP) and narrowest nutritive ratio (NR) values, compared with either the control or other treatments.

Table 3

Averages of nutrients digestibility and feeding values of the experimental diets

\begin{tabular}{|c|c|c|c|c|c|c|c|}
\hline \multirow[t]{2}{*}{ Variable } & \multicolumn{5}{|c|}{ Treatments } & \multirow[t]{2}{*}{ SEM } & \multirow[t]{2}{*}{$P$-value } \\
\hline & $\mathrm{T}_{1}$ & $\mathrm{~T}_{2}$ & $\mathrm{~T}_{3}$ & $\mathrm{~T}_{4}$ & $\mathrm{~T}_{5}$ & & \\
\hline \multicolumn{8}{|c|}{ Apparent digestibilty, \% } \\
\hline Dry matter, DM & 82.9 & 84.1 & 85.8 & 85.6 & 83.1 & 1.50 & 0.53 \\
\hline Organic matter, OM & 85.1 & 86.9 & 88.4 & 88.0 & 86.6 & 1.25 & 0.42 \\
\hline Crude protein, $\mathrm{CP}$ & $79.8^{b}$ & $80.3^{b}$ & $85.9^{a}$ & $85.5^{\mathrm{a}}$ & $83.2^{\mathrm{ab}}$ & 1.53 & 0.05 \\
\hline Crude fibres, CF & 55.1 & 66.7 & 66.1 & 65.9 & 64.0 & 5.11 & 0.50 \\
\hline Ether extract, EE & 86.0 & 88.0 & 89.4 & 89.8 & 88.5 & 1.27 & 0.31 \\
\hline NFE & 89.2 & 90.4 & 90.9 & 90.3 & 89.6 & 0.96 & 0.73 \\
\hline \multicolumn{8}{|l|}{ Feeding values, \% DM } \\
\hline SV & 89.5 & 90.7 & 93.5 & 93.4 & 90.7 & 1.35 & 0.30 \\
\hline TDN & 93.8 & 95.4 & 97.7 & 97.5 & 95.4 & 1.37 & 0.23 \\
\hline DCP & $9.0 \mathrm{~b}$ & $8.9^{b}$ & $9.8^{\mathrm{a}}$ & $9.8^{\mathrm{a}}$ & $9.3^{\mathrm{ab}}$ & 0.17 & 0.01 \\
\hline Nutritive ratio & $9.4^{\mathrm{ab}}$ & $9.7^{\mathrm{a}}$ & $9.0^{b}$ & $9.0^{\mathrm{b}}$ & $9.3^{\mathrm{ab}}$ & 0.15 & 0.02 \\
\hline
\end{tabular}

a,baverages with different superscripts in the same column are significantly $(P<0.05)$ different, Apparent digestibility (\%): [(nutrient intake-nutrient excretion in feces)/nutrient intake] $\times 100$, DCP \% (digestible crude protein): (digested protein/DMI) $\times 100$, TDN \%: digested $C P+$ digested $C F+$ digested NFE+(digested EE $\times 2.25$ ), SV\% (starch value): (digested $\mathrm{CP} \times 0.94)$ +digested $\mathrm{CF}+$ digested $\mathrm{NFE}+($ digested $\mathrm{EE} \times$ variable factor1)-(CF\% $\times$ variable factor2), Nutritive ratio: TDNDCP/DCP; Nagah (2002) 


\section{Lamb performance}

Average LBW, daily weight gain (DWG), dry matter intake (DMI) and feed conversion (FC) of lambs fed experimental diets are illustrated in Table 4. Lambs of More-yeast supplementations $\mathrm{T}_{4}$ and $\mathrm{T}_{5}$ recorded the highest values of $\mathrm{LBW}$, DWG without significant, also, lambs of $\mathrm{T}_{4}$ and $\mathrm{T}_{5}$ consumed the highest amount of daily DMI $(P<0.001)$, whereas, those of $\mathrm{T}_{2}$ and $\mathrm{T}_{3}$ (Pronifer supplemented groups) recorded the lowest amount compared with the control. Data for feed conversion did not show any diet effects.

Table 4

Averages of lamb performance and feed conversion values of lambs fed the experimental diets

\begin{tabular}{lccccccc}
\hline Variable & \multicolumn{7}{c}{ Treatments } \\
& $\mathrm{T}_{1}$ & $\mathrm{~T}_{2}$ & $\mathrm{~T}_{3}$ & $\mathrm{~T}_{4}$ & $\mathrm{~T}_{5}$ & SEM & $P$-values \\
\hline Lamb performance & & & & & & & \\
Body weight, $\mathrm{kg}$ & 55.20 & 54.25 & 54.6 & 60.25 & 58.80 & 3.09 & 0.49 \\
Daily gain, $\mathrm{kg}$ & 0.180 & 0.180 & 0.181 & 0.188 & 0.194 & 0.01 & 0.89 \\
Daily dry matter intake, $\mathrm{kg}$ & $1.175^{\mathrm{b}}$ & $1.135^{\mathrm{c}}$ & $1.161^{\mathrm{bc}}$ & $1.243^{\mathrm{a}}$ & $1.225^{\mathrm{a}}$ & 0.01 & 0.001 \\
Feed conversion & & & & & & & \\
kg DM intake/Kg gain & 6.528 & 6.306 & 6.414 & 6.612 & 6.314 & 0.42 & 0.93 \\
kg SV intake/Kg gain & 5.839 & 5.717 & 5.994 & 6.176 & 5.727 & 0.39 & 0.74 \\
kg TDN intake/Kg gain & 6.122 & 6.017 & 6.265 & 6.447 & 6.021 & 0.41 & 0.78 \\
kg DCP intake/Kg gain & 0.589 & 0.561 & 0.630 & 0.649 & 0.588 & 0.04 & 0.33 \\
\hline
\end{tabular}

$a, b, c$ Averages with different superscripts in the same column are significantly $(P<0.05)$ different.

\section{Ruminal liquor and blood parameters}

Values of ruminal $\mathrm{pH}, \mathrm{NH}_{3}-\mathrm{N}$ and TVFA concentrations of lambs in the different experimental treatments are shown in Table 5.

Table 5

Averages of ruminal $\mathrm{pH}$ and blood parameters values of lambs fed the experimental diets

\begin{tabular}{|c|c|c|c|c|c|c|c|}
\hline \multirow[t]{2}{*}{ Variable } & \multicolumn{5}{|c|}{ Treatments } & \multirow[t]{2}{*}{ SEM } & \multirow[t]{2}{*}{$P$-values } \\
\hline & $\mathrm{T}_{1}$ & $\mathrm{~T}_{2}$ & $\mathrm{~T}_{3}$ & $\mathrm{~T}_{4}$ & $\mathrm{~T}_{5}$ & & \\
\hline \multicolumn{8}{|l|}{ Rumen activity } \\
\hline Ruminal pH & 6.35 & 6.26 & 6.69 & 6.45 & 6.51 & 0.12 & 0.98 \\
\hline $\mathrm{NH}_{3}-\mathrm{N}, \mathrm{mg} / 100 \mathrm{ml}$ & $25.98^{\mathrm{a}}$ & $24.11^{\mathrm{a}}$ & $24.93^{\mathrm{a}}$ & $23.49^{a b}$ & $21.00^{\mathrm{b}}$ & 0.98 & 0.05 \\
\hline TVFA, mg/100ml & 12.34 & 12.42 & 12.49 & 12.34 & 13.07 & 0.39 & 0.99 \\
\hline \multicolumn{8}{|l|}{ Blood parameters } \\
\hline Total protein, g/dl & 6.76 & 7.22 & 7.33 & 7.36 & 7.62 & 0.24 & 0.29 \\
\hline Albumin, g/dl & 4.80 & 4.30 & 4.84 & 4.81 & 4.66 & 0.14 & 0.07 \\
\hline Globulin, g/dl & $1.96^{\mathrm{b}}$ & $2.92^{\mathrm{a}}$ & $2.48^{\mathrm{ab}}$ & $2.55^{\mathrm{ab}}$ & $2.96^{\mathrm{a}}$ & 0.24 & 0.05 \\
\hline $\mathrm{Al} / \mathrm{G}$ ratio & 2.67 & 1.7 & 2.06 & 2.49 & 1.75 & 0.28 & 0.07 \\
\hline Urea,mg/dl & $23.04^{b}$ & $21.52^{b}$ & $24.2^{\mathrm{ab}}$ & $24.5^{\mathrm{ab}}$ & $27.98^{\mathrm{a}}$ & 1.32 & 0.03 \\
\hline Creatinine, g/dl & 1.64 & 1.56 & 1.62 & 1.46 & 1.40 & 0.08 & 0.42 \\
\hline Cholesterol, mg/dl & 58.46 & 58.01 & 56.48 & 54.36 & 47.74 & 3.95 & 0.68 \\
\hline GOT, u/I & 28.74 & 29.18 & 31.84 & 32.41 & 38.73 & 3.54 & 0.53 \\
\hline GPT, u/I & 20.75 & 20.05 & 22.17 & 20.76 & 21.67 & 0.71 & 0.06 \\
\hline
\end{tabular}

\footnotetext{
${ }^{a, b}$ Averages with different superscripts in the same column are significantly $(P<0.05)$ different.
} 
Results showed that the differences in $\mathrm{pH}$ and TVFA values at the different experimental treatment were very limited and without any significant effect. However, differences in $\mathrm{NH}_{3}-\mathrm{N}$ concentration due to treatments effect were significant $(P<0.05)$. Differences in blood plasma concentrations due to treatment effects were seen for globulin $(G)$ and urea $(U)$ concentrations $(P<0.05)$ (Table 5).

\section{Discussion}

\section{Nutrients digestibility and feeding values}

The improvement in nutrients digestibility is possibly explained on the basis that yeast culture enhanced microbial activity and also due to that some beneficial activities of lactic acid bacteria in the gastrointestinal tract, i.e., its anti diarrhoea activities, anti tumour activities and its ability to alter enzyme activities (Dawson 1988).

The main effect of yeast culture supplementation on ruminants include improvement of gut health and ecology through rumen maturity by favouring microbial establishment, stabilisation of rumen $\mathrm{pH}$ and interaction with lactate utilizing bacteria (Yang et al. 2004). The establishment of complex rumen microbial ecosystem subsequently improve rumen function that promotes absorption ability and feed digestion (Hopper et al. 2001), thus live yeast additives improve gut health.

These results are in agreement with those reported by Bohm \& Srour (1995) who reported that supplementing the diet of crossbred calves with $5 \mathrm{~g}$ Pronifer/(kg concentrate $\times \mathrm{d}$ ) improved the digestibility of most feed nutrients. El-Ashry et al. (2003) with sheep and goats, Nagah (2002) and Khattab et al. (2003) with crossbred lambs and Ragheb et al. (2003) with Friesian calves indicated that the digestibility of most feed nutrients improved by yeast culture (YC), yea-sac (YS) or lacto-sac (LS) supplementation. Feeding values have improved with supplementations due to positive effect on digestible tract. Nagah (2002) and Khattab et al. (2003) reported that the use of either $3 \mathrm{~g}$ YS or $3 \mathrm{~g} \mathrm{LS} / \mathrm{h} / \mathrm{d}$ improved SV and TDN values of crossbred lambs. Also, Gado et al. (1998), Salem et al. (2000) and El-Ashry et al. (2003) found that yeast culture supplementations had positive effect on TDN and DCP values of growing lambs.

\section{Lamb performance}

Results showed significant increase in DM intake due to More-yeast supplementation $\left(\mathrm{T}_{4}\right.$ and $\mathrm{T}_{5}$ ). In addition, LBW and DWG are enhanced slightly with growth promoter supplementations probably due to enhance in rumen activity and digestibility.

The active yeast supplementation has positive effects in young ruminant's performance through increased DM intake and daily gain, Thus, The performance promoting effects of live yeast additives could be correlated to an improvement in rumen development parameters such as papillae length and width, and rumen thickness (Lesmeister et al. 2004), early establishment and stabilization of rumen microbial communities (Chaucheyras-Durand \& Fonty 2001, 2002) and reduced number of days of diarrhoea (Galvano et al. 2005). Moreover, YC, YS and LS supplements improved the growth performance of growing lambs (Salem et al. 2000, Fayed 2001, Nagah 2002 and El-Ashry et al. 2003). 
On the other hand, supplements had no significant effects on FC agreement with Nagah (2002) and El-Ashry et al. (2003), they indicated that YC, YS and LS supplements had no effect on feed conversion values (as DM, TDN and DCP/kg gain) of growing lambs. Similarly, Mir \& Mir (1994) with steers and Ragheb et al. (2003) with Friesian calves found that live yeast and LS had no positive effect on feed utilization values ( $\mathrm{kg}$ gain/kg DM, TDN and DCP).

\section{Ruminal liquor parameters}

The significant differences in the values of ruminal $\mathrm{NH}_{3}-\mathrm{N}$ showed the lowest value $\mathrm{T}_{5}$. In accordance with the previous results, Nagah (2002) and Mussa (2001) reported that the ruminal $\mathrm{NH}_{3}-\mathrm{N}$ concentrations for $\mathrm{YS}$ and LS supplementations were lower than the control but the differences were not significant.

The reduction in ruminal $\mathrm{NH}_{3}-\mathrm{N}$ of More-yeast treated animals in the present study may be probably attributed to the inhibitory effect of this growth promoter on proteolysis amino acid deamination and ruminal urease activity (Fuller \& Johnson 1981, Starnes et al. 1984 and Gomez et al. 1991).

The mechanism of yeast action may be due to competition between yeast cells and the bacteria for energy supply and by a direct inhibitory effect of yeast on small peptides and bacterial peptidases (Chaucheyras-Durand et al. 2008). Yeast culture supplementation is reported to enhance microbial growth and decrease $\mathrm{N}$ loss by incorporating more digestible carbohydrates into microbial mass (Sniffen et al. 2004).

\section{Blood parameters}

The differences in plasma globulin concentrations between $T_{1}$ and $T_{2}$ or $T_{5}$ were significant, whereas no significant differences were observed among other treatments. Sadik (1989) found that lactobacillus concentrate supplement significantly increased plasma globulin concentrations for buffalo heifers. Also, Mohanna (2000) with lactating buffaloes, Salem et al. (2000) with growing crossbred sheep, and El-Ashry et al. (2003) with Barki lambs, reported that YC supplementation significantly increased plasma $G$ values.

Result obtained revealed that plasma urea concentration in blood plasma of lambs fed the experimental diets ranged from $21.52 \mathrm{mg} / \mathrm{dl}$ for $\mathrm{T}_{2}(1.5 \mathrm{~kg}$ Pronifer/Mg CFM supplemented group) and $27.98 \mathrm{mg} / \mathrm{dl}$ for $\mathrm{T}_{5}$ (5 kg More-yeast/Mg CFM supplemented group). The differences in plasma urea concentrations were only significant between $\mathrm{T}_{5}$ and those of $\mathrm{T}_{1}$ and $T_{2}$, whereas no significant differences were detected between other treatments. Ragheb et al. (2003) who reported that dietary YS and LS supplementation increased blood plasma urea concentrations compared with the control group.

In general results of blood plasma parameters for lambs fed the experimental diets indicated that all treatments had little effect on blood plasma parameters estimated in the present study as the differences in all parameters due to treatment effect were not significant except for globulin and urea values.

However, values of most blood plasma parameters estimated in the present study are within the normal ranges for ruminants published by several workers in the literatures (Owen et al. 1954, Mahmoud 1993, Nagah 2002, EL-Ashry et al. 2003 and Ragheb et al. 2003), and 
suggested that the experimental growth promoters are safe for physiological and healthy status of all experimental lambs.

In conclusion, supplementation of probiotics as growth promoters (Pronifer and Moreyeast) in diets of growing lambs enhanced protein digestibility and dry matter intake, whereas these supplements had little effect on feed conversion and rumen activity. Both, Pronifer and More-yeast supplementation in diet improved plasma globulin which may be related to immunity in these animals.

\section{Acknowledgements}

We thank all staff of animal production department and all workers in farm animals and experimental units in faculty agriculture, Benha University, Egypt.

\section{References}

Abou-Akkada AR, El-Shazly K (1964) Effect of Absence of Ciliate Protozoa From the Rumen on Microbial Activity and Growth of Lambs. Appl Microbiol 12, 384-390

Allain CC, Poon LS, Chan CGS, Richmond W, Fu PC (1974) Enzymatic Determination of Total Serum Cholesterol. Clin Chem 20, 470-475

AOAC (1990) Official Methods of Analysis of the Association of Official Analytical Chemists. Association of Official Analytical Chemists, 15th ed., Arlington, VA, USA

Armstrong WD, Carr CW (1964) Physiological Chemistry: Laboratory Direction. 3rd edition, Birgess Publishing Company, Minneapolis, MN, USA, 75

Bohm J, Srour A (1995) An Austrian probiotic feed additive for Egyptian buffalo and cattle production. 3rd Scientific Conference, Faculty of Veterinary Medicine, Assiut University (Egypt Society for Cattle Diseases), Dec 3-5, Assiut, Egypt

Chaucheyras-Durand F, Fonty G, Bertin G, Gouet P (1995) Effects of live Saccharomyces cerevisiae cells on zoospore germination, growth, and cellulolytic activity of the rumen anaerobic fungus, Neocallimastix frontalis MCH3. Curr Microbiol 31, 201-205

Chaucheyras-Durand F, Fonty G (2001) Establishment of celluloytic bacteria and development of fermentative activities in the rumen of gnotobiotically-reared lambs receiving the microbial additive Saccharomyces cerevisiae CNCM I-1077. Reprod Nutr Dev 41, 57-68

Chaucheyras-Durand F, Fonty G (2002) Influence of a Probiotic Yeast (Saccharomyces cerevisiae CNCM I-1077) on Microbial Colonization and Fermentation in the Rumen of Newborn Lambs. Microbial Ecol Health Dis $14,30-36$

Chaucheyras-Durand F, Walker ND, Bach A (2008) Effects of active dry yeasts on the rumen microbial ecosystem: Past, present and future. Anim Feed Sci Technol 145, 5-26

Conway EJ (1962) Microdiffusion Analysis and Volumetric Error. 5th ed., Crosby Lockwood \& Son Ltd., London, UK

Cremonini F, Di Caro S, Nista EC, Bartolozzi F, Capelli G, Gasbarrini G, Gasbarrini A (2002) Meta-analysis: the effect of probiotic administration on antibiotic-associated diarrhoea. Aliment Pharmacol Ther 16, 14611467

Dawson KA (1988) Manipulating ruminal fermentations: Are there natural alternatives to ionophores for beef production? In: Lyons TP (ed.) Biotechnology in the Feed Industry. Proceedings of Alltech's 4th Annual Symposium. Alltech Technical Publications, Nicholasville, KY, USA, 101-112

Dawson KA (1992) Current and future role of yeast cultures in animal production: A review of research over the last six years. In: Lyons TP (ed.) Biotechnology in the Feed Industry. Proc Alltech's 8th Annual Symposium (Supplement). Alltech Technical Publications, Nicholasville, KY, USA, 1-23 
Dawson KA (1993) Current and future role of yeast culture in animal production: A review of research over the last seven years. In: Lyons TP (ed.) Biotechnology in the Feed Industry. Proceedings of Alltech's 9th Annual Symposium. Alltech Technical Publications, Nicholasville, KY, USA, 169-171

Dawson KA, Neuman KE, Boling JA (1990) Effects of microbial supplements containing yeast and lactobacilli on roughage-fed ruminal microbial activities. J Anim Sci 68, 3392-3398

Doumas BT, Watson WA, Biggs HG (1971) Albumin standards and the measurement of serum albumin with bromcresol green. Clin Chim Acta 31, 87-96

Duncan DB (1955) Multiple Range and Multiple F-Tests, Biometrics 11, 1-42

El-Ashry MA, Fayed AM, Youssef KM, Salem FA, Hend AA (2003) Effect of feeding flavomycin or yeast as feed supplement on lamb performance in Sinai. Egypt J Nutr Feed 6 (Special Issue), 1009-1022

El-Waziry AM, Kamal HE, Yacont MH (2000) Effect of baker's yeast (saccharomyces cerevisiae) supplementation to berseem (Trifolium alexandrium) hay diet on protein digestion and rumen fermentation of sheep. Egypt J Nutr Feed 3, 71

Fayed AM (2001) Effect of using yea-sacc on performance of sheep and goats in Sinai. Egypt J Nutr Feed 4 (Special Issue), 67-80

Fuller JR, Johnson DE (1981) Monensin and Lasalocid Effects on Fermentation in Vitro. J Anim Sci 53, 1574-1580

Gado HM, Metwally AM, Salem FA (1998) Effect of yeast culture and monensin on the performance of Baladi goats fed ensiled potato. Ain Shams University, Egypt, Ann Agri Sci 43, 419-429

Galvão KN, Santos JE, Coscioni A, Villlaseñor M, Sischo WM, Berge AC (2005) Effect of feeding live yeast products to calves with failure of passive transfer on performance and pattern of antibiotic resistance in fecal Escherichia coli. Reprod Nutr Dev 45, 427-440

Gillespie JR (1987) Animal nutrition and feeding. Delmar Publishers Inc., Albany, NY, USA

Gomez L, Bogaert C, Jouany JP, Lassalas B (1991) The influence of lasalocid and cationomycin on nitrogen digestion in sheep: Comparison of methods for estimating microbial nitrogen. Can J Anim Sci 71, 389-399

Henry RJ (1964) Clinical chemistry. Principles and technics. Hoeber Medical Division, Harper \& Row, NY, USA, 293

Hopper LV, Wong MH, Thelin A, Hansson L, Falk PG, Gordon JI (2001) Molecular analysis of commensal hostmicrobial relationship in the intestine. Science 291, 881-884

Khattab HM, Salem FA, Sayed MM, Nagah HM (2003) Effect of yea-sacc, lacto-sacc supplementation and energy levels on performance, rumen activity, some blood constituents and carcass traits in growing sheep. Egypt J Nutr Feed 6 (Special Issue), 991-1007

Lesmeister KE, Henrich AJ, Gabler MT (2004) Effects of supplemental yeast (Saccharomyces cerevisiae) culture on rumen development, growth characteristics, and blood parameters in neonatal dairy calves. J Dairy Sci 87, 1832-1839

Mahmoud SZ (1993) Effect of radiation treatment on nutritive value of poultry wastes. Ph D Thesis, Faculty of Agriculture, Ain Shams University, Cairo, Egypt

Mir Z, Mir PS (1994) Effect of the addition of live yeast (saccharomyces cerevisiae) on growth and carcass quality of steers fed high-forage or high-grain diets on feed digestibility and in situ degradation. J Anim Sci 72, 537-545

Mohanna AA (2000) The use of non-hormonal growth enhances with different nutritional levels for growing Friesian calves until slaughter. M Sc Thesis, Faculty of Agriculture, Ain Shams University, Cairo, Egypt

Mussa KM (2001) Effect of some feed additives on milk yield and composition of lactating buffaloes fed on silage. Ph D Thesis, Faculty of Agriculture, Ain Shams University, Cairo, Egypt

Nagah HM (2002) Use of growth promoters (non-hormonal) in rations of growing lambs. M Sc Thesis, Faculty of Agriculture, Ain Shams University, Cairo, Egypt

NRC (1985) Ruminant Nitrogen Usage. National Academy of Science, National Academy Press, Washington DC, USA 
Owen JA, Iggo B, Scandrettm FJ, Stewart CP (1954) The determination of creatinine in plasma or serum, and in urine; a critical examination. Biochem J 58, 426-437

Patton CJ, Crouch SR (1977) Spectrophotometric and Kinetics Investigation of the Berthelot Reaction for the Determination of Ammonia. Anal Chem 49, 464-469

Ragheb EE, Mehriz AF, Abdel-Khalik AE (2003) Digestibility coefficients, blood parameters, feed efficiency and growth performance of weaned Frisian calves fed diet supplemented with lacto-sacc. Egypt J Nutr Feed 6 (Special Issue), 693-702

Reitman S, Frankel S (1957) A colorimetric method for the determination of serum glutamic oxalacetic and glutamic pyruvic transaminases. Ann J Clin Pathol 28, 56-63

Sadik MF (1989) Effect of lactobacillus concentrate (LBC) as a new growth promoter on the performance of growing buffalo heifers raised on milk replacer. M Sc Thesis, Faculty of Agriculture, Ain Shams University, Cairo, Egypt

Salem FA, Soliman AS, Abd El-Mawla SM, El-Mahdy MR (2000) Effect of some feed additives added to diets of growing sheep on performance, rumen fermentation, blood constituents and carcass characteristics. Benha University, Egypt, Ann Agric Sci Moshtohor 38, 1885-1904

SAS (1999) SAS/STAT User's Guide, Version 8, SAS Institute Inc., Cary, NC, USA

Sniffen CJ, Chaucheyras-Durand F, De Ondarza MB, Donaldson G (2004) Predicting the Impact of Live Yeast Strain on Rumen Kinetics and Ration Formulation. Proc. Southwest Nutrition and Management Conference,Tempe, AZ, USA, 53-59

Srour A, Ragheb MF, Shoeib HK (2000) Health response of one humped camel to probiotic Pronifer supplementation. Egypt J Agri 78, 137-144

Starnes SR, Spears JW, Froetschel MA, Croom WJ Jr. (1984) Influence of monensin and lasalocid on mineral metabolism and ruminal urease activity in steers. J Nutr 114, 518-525

Tripathi MK, Karim SA (2011) Effect of yeast cultures supplementation on live weight change, rumen fermentation, ciliate protozoa population, microbial hydrolytic enzymes status and slaughtering performance of growing lamb. J Livest Sci 135, 17-25

Windschitl PM (1992) Effects of probiotic supplementation of hull-less barley- and corn-based diets on bacterial fermentation in continuous culture of ruminal contents. Can J Anim Sci 72, 265-272

Yang WZ, Beauchemin KA, Vedres DD, Ghorbani GR, Colombatto D, Morgavi DP (2004) Effects of direct-fed microbial supplementation on ruminal acidosis, digestibility, and bacterial protein synthesis in continuous culture. Anim Feed Sci Technol 114, 179-193

Received 16 March 2011, accepted 11 July 2011.

Corresponding author:

Hany Hillal

email: hany.helal@fagr.bu.edu.eg

Department of Animal Production, Faculty of Agriculture, Benha University, Egypt 